Discourse and Communication for Sustainable Education, vol. 10, no. 2, pp. 100-111, 2019

\title{
Entrepreneurship Education in a Democratic Perspective
}

\author{
Britt Due Tiemensma and Connie Stendal Rasmussen \\ University College Absalon, Roskilde, Denmark
}

\begin{abstract}
Entrepreneurship Education often emphasizes the practical applications of competencies. This article aims to collect findings on entrepreneurship education linked to democratic formation in primary education as experienced by teacher students. Based on a model from the Danish Foundation for Entrepreneurship and theories on democratic formation and active citizenship, the authors analyze what entrepreneurship and democratic formation have in common. Entrepreneurship education will also be linked to education for sustainable development. By following a group of teacher students in two different cases, the authors discuss how a potential synergy is visible, when the teacher students learn by reading, discussing and solving concrete tasks connected to social entrepreneurship education. The teacher students' personal attitudes and understanding of authentic practical experiences turns out to be important to their learning from entrepreneurial education tasks. The structural organization of teacher education is a challenge to the organization of teaching entrepreneurship education.
\end{abstract}

Key words: entrepreneurship, democratic formation, attitude, creativity, sustainability.

\section{Introduction}

Competences in innovation and entrepreneurship as well as democratic citizenship have been part of the Danish teacher education program in various disciplines for more than 10 years. Teacher students learn to address and share problems in a community and learn how to act in an NGO or political sphere. Based on a presumption of a complex relationship between entrepreneurship education and democratic formation, teacher students can be introduced to generating ideas for the common good as the core of entrepreneurship education. The understanding of the common good as a principle of orientation depends on the type of society, and in this context it will be understood as maintenance and development of democracy as a way of living and as a system of governing. The question we tried to answer is how the relationship between entrepreneurship education and civic learning can be addressed by teacher students in primary education.

In this article the framework for civic learning will be based on Gert Biesta's (2011) understanding of citizenship education. He distinguishes between 
- learning about democracy as a process of acquisition of knowledge and skills to be socialized into an existing sociopolitical order,

- or learning from democracy as a process of subjectification where students sense democracy as experimentation with systems out of order, and thus always in a process of transformation.

Our framework for entrepreneurship education is mostly based on research and recommendations from The Danish Foundation for Entrepreneurship, an inter-ministerial partnership aimed at creating a coherent strategy for innovation and entrepreneurship at all levels of education in Denmark since 2010. To illustrate how entrepreneurship and democratic citizenship education can be interdependent we present two cases:

- In the first case, the framing of learning was creation of games as a creative and sustainable process for fourth grade students.

- In the second case, the framing was establishing a sustainable community or school garden at a Danish university college.

The cases link an entrepreneurial mindset to the teacher students' creativity, design thinking and sustainability, but also expose a number of the structural challenges to innovation and entrepreneurship in the Danish teacher education program. Sustainable learning, in our opinion, contains four basic principles (Eskisi 2019):

1. Deep and Broad Learning: Deep and broad learning is about learning details as well as related concepts together, the use of learning opportunities when they arise, and creating opportunities for learning as much as possible.

2. Learning through transfer: Transfer is described as applying what is learned to a different situation and associating such learning with daily life.

3. Learning through dissemination: That means learning through sharing and disseminating what is learned and to convey content to other people and future times.

4. Learning by thinking ahead: It means that individuals decide what they will learn by considering the future. Due to rapid development of the society, school learning can seem irrelevant and useless in their future lives. To prevent it, what they learn, must be for the future.

In this article, teacher student refers to a student studying to become a teacher in a primary and lower secondary school and student refers to children and young people studying at any level. We will not be discussing entrepreneurship as a driver of the economy; instead we focus on social entrepreneurship, democratic formation and how they might benefit from each other.

\section{Entrepreneurship Education}

The development of entrepreneurial skills and mindset is one of eight key objectives for lifelong learning defined by the European Commission and in the recommendation from 2018, the national education systems are encouraged to promote entrepreneurship skills, creativity and sense of initiative, especially among young people (European Commission, 2018, p. 189). Over the years in Europe, entrepreneurship education has become an established model of lifelong learning. However, the term seems to be understood fundamentally differently: on the one hand as "an adaptation of the individual to a certain socio-economic logic" and on the other as "a liberating educational opportunity to give more people a greater say in their lives" (Rasmussen, Moberg \& Revsbech, 2015, 
p. 12). As a result of these differences, various approaches have developed: one school's main focus will be on training students to become drivers of economic and social dynamics in the local community, while other schools focus on competencies in social entrepreneurship. Thus, the concept of entrepreneurship education is far from clear. So far, no European consensus has been established on entrepreneurship education. Entrepreneurship education is implicated in a wider cultural, social, political and economic order and the aim can be fostering independent business protagonists with innovative power and skills to develop new products. At its core, the neoliberal European education policy has focused on individualization, standardization and accountability. Students must be job-ready, when they finish their education, but what about growing as democratic citizens with common values and fundamental rights? This is also part of the overall objectives of the Danish primary education.

For primary and lower secondary education, the Danish Ministry of Education has adapted the definition "Entrepreneurship is when you act upon opportunities and ideas and transform them into value for others. The value that is created can be financial, cultural or social". The definition was originally proposed by The Danish Foundation for Entrepreneurship and later presented by EntreComp (McCallum et al., 2018, p. 8). This definition is centered on the creation of values and it establishes a relationship between an individual or individuals and others. Entrepreneurship education can take place when one or more students open up an opportunity or idea by researching. They also learn to visualize and concretize how their idea or opportunity will affect others. Step by step they produce solutions. Students may learn how important empathy is. They are encouraged to use their knowledge and skills in a creative way to provide value or common good by trying to meet the needs of others.

This approach might be understood as driven by an idealistic or ethical understanding of human beings and as committed to producing objects or materials of value for others; however, the term can also be understood in a pragmatic way. To open up an opportunity in entrepreneurial education involves engagement in a dialogue. With reference to John Dewey (Dewey, 1929, p. 185), it will be assumed that human beings come into existence through and as a result of communication. When students experience a value-creating process for themselves and others by having a social environment in which their activities are associated with other human beings' engagement in problemsolving activities, entrepreneurship education can be facilitated. Gert Biesta has phrased the importance of communication more poetically:

"To exist as a subject, as I will suggest, means being in a "state of dialogue" with what and who is other; it means being exposed to what and who is other, being addressed by what and who is other, being taught by what and who is other, and pondering what this means for our existence and for the desires we have about our existence" (Biesta, 2017, p. 4).

Entrepreneurial education involves interchange and raises normative questions based on value systems as well as questions to be answered, depending on subjects' knowledge and skills. Understanding these relationships and learning to take responsibility for their functioning are matters of craft as well as ethics and both must be addressed in entrepreneurship education. To illustrate the core competencies in entrepreneurship education, the Danish Ministry of Education has presented a graphic model (fig. 1) and here attitude is understood as the core competence influencing and being influenced by creativity, action and outward orientation. The model also illustrates that the core curricula or 
subjects are framing teaching and learning and that these competences are understood as part of the overall educational objective in primary education; to equip students as being co-creators of their own life in a changing world.

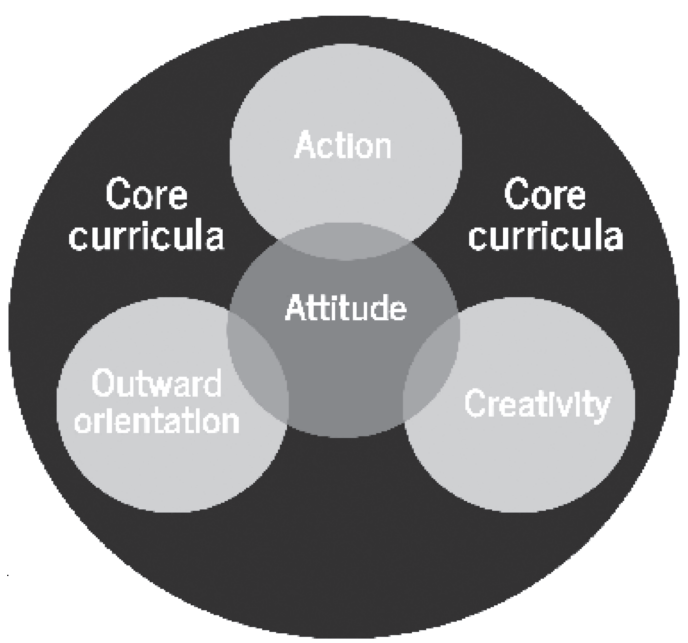

Figure 1. The four entrepreneurial dimensions embedded in the core curricula of educational institutions (Rasmussen, Moberg, Revsbech, 2015, p. 12)

The Danish model (fig. 1) has four competencies instead of three and thus it is a little different from the recommendation by The European framework for entrepreneurship education (EntreComp). The additional competence attitude is bringing in the importance of personal/ethical attitudes in entrepreneurship education. To illustrate the dependence on value systems, we focus on democracy and "the idea that the democratic experiment should be understood as a process of transformation" (Biesta et al., 2014, p. 7). The dynamics between individuals or groups and the interest of the common good will depend on a given context. Awareness of attitude gives a sense of direction and enables students to answer if a specific idea or product is moving them or things in the intended direction, and thus attitude draws the attention to the normative aspects of entrepreneurship education.

To be successful, however, streams of psychological research indicate that attitude change will translate into behavior change when including factors as "intention specificity, action difficulty, contextual support, habitual behavior" and thus to succeed, specific strategies must be applied in Education programs (Arbuthnott, 2009, p. 161).

\section{Democratic Formation}

In this paragraph we present our theoretical approach to democratic formation, method and our findings on the teacher students' approaches to democratic formation. We will also try to substantiate how entrepreneurship education and democratic formation may support each other to meet the overall objectives of the Danish primary education.

Method: In the spring of 2019, we observed and lectured in an entrepreneurship module for 14 weeks, and observed in two one-week courses on entrepreneurship for teacher students. The data gathered here will be the foundation of this article. The aim 
was mapping links between entrepreneurship education and democratic formation in the teacher education program. We collected observations on teacher students' understanding of democratic formation and entrepreneurship education and we used questionnaires and informal interview.

Entrepreneurship education and democratic formation has been observed in and outside classrooms, and these observations and interviews have been analyzed and put into perspective based on educational philosophy and methods. We observed that the teacher students' attitudes and democratic formation approaches were based on an understanding of active and experimenting citizenship described in the following three dimensions (Fig. 2):

1. Knowledge Dimension; to give students knowledge about democracy, politics, citizenship and social conditions,

2. Value Dimension; to create confidence in democratic values; equality, respect, freedom, tolerance and solidarity,

3. Handling Dimension; To develop citizenship skills such as collaboration skills, handling conflicts, participation, dialogue, reflection and critical thinking (Jarvis 2010, Korsgaard 2001)

These three dimensions in primary education encouraged the teacher students to work with a complex approach to democratic formation without describing a definite objective for the process to become responsible adult citizen in the world. In the classroom, the three dimensions were mixed. Teacher students were learning to perform using mandatory interdisciplinary topics and at the same time indirectly taking responsibility for ensuring that the students were introduced to democracy as a way of living by the way they communicate and interact with them. The formation task, when it came to democracy, was understood as an overall or implicit task, which was not in itself assigned to teaching lessons, but implemented by the individual teacher student in communication. In the classroom we observed that democratic formation without real content and without lessons becomes an almost impossible task for the teacher students, but it was considered to be a very important task.

Why was democratic formation so important to the teacher students? The three dimensions of democratic formations can be identified in the first paragraph of The Danish School Act often referred to as The Mission Statement and thus part of the overall aim of primary education:

"The 'Folkeskole' (public school) must prepare pupils for participation, joint responsibility, rights and duties in a society of freedom and democracy. School work must therefore be characterized by intellectual freedom, equality and democracy." (Børne og Undervisningsministeriet, 2017)

The schools are expected to be committed to providing age-appropriate knowledge on democracy, supported by skills that allow democracy to unfold in many different ways. Democratic formation is the individual's upbringing to become part of a society. There is a contradiction in this composition. Formation is in itself a very subjective and individual development, and democracy is a piece of reality that one can decide on or escape from, according to insight and consciousness. Karsten Schnack, professor of General Education formulates the mission in the following simple way: "... the school's general $\operatorname{task}(\mathrm{s})$ - to create opportunities to understand the world and intervene in it" (Schnack, 1992, p. 15). He advocates that political formation is a necessary part of 
democracy and it must take place in school in an interdisciplinary problem-oriented education. It is based on the children's experiences and must offer challenges and provoke them so that new understandings and concepts about the world can arise and be challenged. He defines democracy as participation, thus the task is to educate and qualify students as active participants in a civic society. "In a democracy, members are not spectators, but participants. Not equally active participants in everything all the time, of course, but always potential participants, who themselves assess, in what and when, you get involved. Education for democracy is therefore also upbringing and qualification for the participant role." (Schnack, 1992, p. 52).

Students may learn to navigate drawing upon previous experiences, and if they are challenged and provoked through the activities in the classroom, participation can become a means to acquire competences. To develop democratic formation in schools, students need to practice the role as involved participants. An example could be that in some places trash becomes a social and a political challenge when left on the streets or in schools by individuals and picked up by the municipality at the cost of the citizens. There is not a right or wrong solution and there is no linear process to change mindsets. When teaching civic learning as knowledge and skills in a classroom the outcome might not influence students' way of living.

The three democratic formation dimensions might not be considered to be equally important by teachers or management in schools. In 2016 an International Civic and Citizenship Education Study (ICCS) was published on how the schools prepare students to live in a democratic society. The study was based on data from 15 -year-old-students at 3800 schools in 24 countries. The study focuses on the students' knowledge and skills in the social sciences and on the students' attitudes, values and activities in school and in society. The Danish students had the highest score overall on knowledge about democracy, but they scored very low on the importance of active citizenship. The concept was understood by Danish students as adding little value to their lives (Bruun et al., 2017, p. 26). The ICCS study pinpoints some of the conscious or unconscious attitudes and values students in different countries may bring to entrepreneurship education. Attitude is understood as an important driver in the Danish entrepreneurship education model (Figure 1), but students might not think of attitude as influenced by democratic values such as equality and freedom of spirit because they only associate democracy with the knowledge dimension and do not experience it as their own fundamental value in action. In this perspective, civic learning might benefit from entrepreneurship education.

\section{Democratic Formation and Social Entrepreneurship Education - What do They Have in Common?}

By comparing the content from the Entrepreneurship Education model, and the Democratic Formation model, we want to visualize the overlaps and the potential synergy in the model below. Some of the features in this area of competences seem to be overlapping and in our opinion, these features may be able to create even more clever entrepreneurs.

In the model, Figure 2, there are several common features. The feature action is an obvious starting point. Teacher students in Entrepreneurship Education are expected to be involved in practical activities, cross-cutting different subjects, and to create value for others. In Entrepreneurship Education, some ideas will make a breakthrough when 
they have been examined, chosen and maybe turned into a prototype. In Democratic Formation, action means dialogue, reflection and critical thinking, which supports the choice of what is for the common good.

Throughout the process, the teacher students are communicating about their activities and therefore they experience how important it is to be able to approach others during the process. The outward orientation from Democratic Formation can facilitate the communication with others. Based on Democratic Formation, teacher students may meet others with respect and understanding, and consecutively they have been learning to handle conflicts and thus promoting effective communication about their activities.

Value is a consistent feature in both. In Democratic Formation the democratic values are in focus, and both ethnicity and social background create an inclusive arena where respect and tolerance may develop. In the Entrepreneurship Education attitude emphasizes a human centered competence and thus a normative aspect of entrepreneurship education. Teacher students stimulated in philosophical and ethical independence are trained in critical thinking also to be used in Entrepreneurship Education.

\begin{tabular}{|l|l|l|}
\hline \multirow{2}{*}{$\begin{array}{l}\text { Entrepreneurship } \\
\text { Education }\end{array}$} & $\begin{array}{l}\text { action } \\
\text { launch initiatives and achieve these through } \\
\text { collaboration }\end{array}$ \\
\cline { 2 - 3 } & $\begin{array}{l}\text { outward } \\
\text { orientation }\end{array}$ & $\begin{array}{l}\text { observe, analyse and construct a social, cultural, } \\
\text { economic context as an arena for actions and activities } \\
\text { that create values }\end{array}$ \\
\cline { 2 - 3 } & creativity & $\begin{array}{l}\text { able to identify and create ideas and opportunities, to } \\
\text { achieve divergent and abductive thinking } \\
\text { combine knowledge from different fields in new ways }\end{array}$ \\
\hline \multirow{2}{*}{$\begin{array}{l}\text { Democratic } \\
\text { Formation }\end{array}$} & actitude & $\begin{array}{l}\text { personal and inter-subjective resources on } \\
\text { perspective, reaction, position, orientation, approach }\end{array}$ \\
\hline value & $\begin{array}{l}\text { collaboration skills, handling conflicts. dialogue, } \\
\text { participation, reflection and critical thinking }\end{array}$ \\
\cline { 2 - 3 } & knowledge & $\begin{array}{l}\text { confidentiality with democratic values; equality, } \\
\text { respect, freedom, tolerance and solidarity }\end{array}$ \\
\cline { 2 - 3 } & action & democracy, respect, freedom, tolerance and solidarity \\
\hline
\end{tabular}

Figure 2. Comparison between Entrepreneurship education and democratic formation (authors' graphic)

Attitude can be ignored in the European EntreComp model, however, students, teaching material and student teachers will bring attitudes into the EE projects anyway and thus, values are at stake. By openly addressing attitudes in Entrepreneurship Education, they are not just hidden drivers but understood as intended and the process becomes more transparent - from idea to some kind of outcome.

The Knowledge dimension in Democratic Formation is somehow missing in Entrepreneurship Education, although it might be incorporated in the outward orientation. To add this dimension to Entrepreneurship Education seems very useful because knowledge about how society works is a good precondition for creating value for others. 


\section{Two Cases}

So far, we have presented approaches to Entrepreneurship Education and Democratic Formation showing that they have mutual features of interest when planning entrepreneurial projects in primary education. In the following paragraphs we focus on two cases from a teacher education course and here also education for sustainable development will be introduced. "Entrepreneurship Education emphasizes the practical applications of competencies. By adopting a framework that provides the basis to make a judgement on the sustainability of an activity..."entrepreneurship education could enable entrepreneurs to make practical decisions on the sustainable development implication of their activities." (Strachan, 2018, p. 43). The global climate crisis has been perceived as framing the future on this planet and already in 1980/90's the crisis was used to train students' understanding of the need for more sustainable development. The UN Brundtland Commission had defined sustainable development as "Meeting the needs of the present without compromising the ability of future generations to meet their own needs" (Report of the World Commission on Environment and Development, 1987). The definition points towards taking action in our time with potential consequences for future generations and even though the concept may not be all that clear it may be understood as a stepping-stone towards the UN 17 goals for 2030 to achieve a more sustainable future on this planet.

These goals can become a period of transition where teacher students get new opportunities to develop their attitudes, for example to sustainable consumerism - by using recycled and natural materials in classroom assignment. (Ashworth and Steele, 2016, p. 44). To facilitate these technical and value-based changes, the module introduced the students to Entrepreneurship Education and to sustainability, i.e. problems can be tackled by applying the proper learning strategies. In Denmark $80 \%$ of primary education students grew up as urban citizens without an intimate relationship with nature and food production. Schools have responded by creating curriculum-based outdoor activities, for example specific subjects or interdisciplinary approaches like school gardening, that can be moved outside. Focus in the second case is how teacher students can meet these needs. In the first case focus is on entrepreneurship education, sustainable and civic learning and games.

Case-study as method is interesting for us because we examine a phenomenon that goes on within the frame of its own life, and as researchers, we must meet other people on their conditions. Case-study is meeting people in their context, which means that the context can change, because people act and learn. (Johansen \& Tetzschner 2006, p. 78-79)

\section{Case 1: Inventing a Game for $4^{\text {th }}$ Grade}

In this case, 12 teacher students, 5 Danish and 7 international students had a task of inventing a new game for $4^{\text {th }}$ grade on civic learning and afterwards they tried out their game in two different classes. The teacher students had to evaluate their product and they had to go back and improve the games according to the students' feedback. At the end, the teacher students evaluated each others' reinvented games.

The process started with the teacher students playing a complex game about multilayered democracy. They discussed different ways to become a social entrepreneur in theory and practice; they had read and interpreted articles; and they had been working with many different practical approaches to entrepreneurship. Afterwards, the teacher students were given the following task in groups: 
1. You must invent a game in your group, where pupils in $4^{\text {th }}$ grade can test and develop democratic skills. You may start with a well-known game (card, ball, board, or computer) and develop from there. You can also develop a new game from scratch.

2. You must include 1 or 2 UN 2030 goals in the game.

3. You must include the purpose of the primary school (Folkeskolens form 1 www.uvm.dk) in your games.

4. You are only allowed to use recycled materials for the game.

5. ... and you must describe the purpose of the game so that the pupils will understand perfectly what you mean. The pupils in $4^{\text {th }}$ grade must be able to play the game in approx. 20-25 minutes.

The teacher students worked on their games for two weeks, and presented them for each other, in order to give friendly critical feedback. They had very good questions and comments like "How does this game develop democratic skills"? or "If you do this, it will be easier for the children to understand". We went to a local school to test the games in $4^{\text {th }}$ grade, while we, the teachers and the university college lecturers, observed the practice carefully. The teacher students had created very different games, and had very useful evaluations from the students, which they immediately transformed into improved games. In the end, the teacher students played the games in the teacher education program, and we discussed how teachers can get pupils to develop games with an entrepreneurial focus.

\section{Case 2: Creating a Garden for Students}

The second case was about creating a community or school garden for teacher students at a university college, and the groups worked on this task for three weeks. The location was on the outskirts of town, close to the highway and railway. Most of the initiators were interested in experiential learning and sustainability and they had little knowledge on gardening. Small things can be important to the entrepreneurial mindset as well as understanding the overview about the financing and UN 2030 goals, and therefore, the narrative about the initiative will be constructed with some details as well as generalizations.

To create attention on the community garden project, the teacher students invited other teacher students to attend a workshop on gardening and transforming old potatoes and overripe tomatoes into new plants. At the workshop, the participants used trash materials, old tins, flowerpots made of transparent and opaque plastic as plant containers. They experimented with self-irrigation systems and making windows in the plastic containers to be able to see how the potatoes evolved. The outcome for the teacher students can be difficult to describe. For example, observing an old wrinkled potato turning into a budding new potato plant growing in an old can is about trash turned into value. The word trash has many negative connotations such as worthless or low quality. Trash creates climate crises on land, in the sea and air. At the end of people's production or consumption, trash remains. In this project, trash instead became a poetic way of creating life.

The next step was to find out about the possibility of establishing a school or community garden on a university college campus. The teacher students used a designthinking method to learn about community/school gardening and the interests of 
stakeholders, students, canteen staff, facility service and management. A proposal for a community garden was developed by the teacher students but turned down by the stakeholders as too time-consuming, expensive and unrealistic. As an alternative, plant containers were introduced to be placed at a nearby student residence. They were much cheaper when made from trash and they would stick out next to a new institution building. A prototype of recycled wood was developed and at the local Makerspace, it could be further developed. The nearby Makerspace is a member-driven association that gathers do-it-yourself people, inventors and geeks of all ages and levels, and teacher students can use the place to develop their products. These workshops are located in an old industrial building so different from a university college building with multifunctional classrooms where teacher students not are allowed to work with tools and wood.

\section{Discussion}

The teacher students' evaluations, the questionnaires and informal interviews showed that it is possible to work on entrepreneurship education and at the same time on democratic formation, and that teacher students' attitudes are very important for coping with their own learning processes. Did we reach our goals? In many ways it is a YES. The teacher students' evaluations showed that they perfectly understood and used elements from the democratic formation and from entrepreneurship education when working on the games. "It made perfect sense that we should invent games and test them in school. It was a great experience for us and for the children. They learned a lot in the democratic field, and so did we. And the children were very entrepreneurial" (Student evaluation June 2019).

The processes were great for the teacher students, and their energy and enthusiasm on the practical level was high and they also used their theoretical knowledge to develop the pupils' skills in the games. The global perspective seems to be missing, however, it is the first time we have tested these cases, so we can improve here. The teachers in the school were very fond of the games and asked the students to copy and develop them afterwards. The teacher students perceived this part of the course as an authentic practical experience and their understanding of their own learning as a process where qualification, socialization and subjectification could not be distinguished but supported each other (Biesta, 2017, pp. 28-29). With reference to Biesta, they were learning from democracy.

In the community/school garden project, the relationship between entrepreneurship and democratic formation was more unclear. To study entrepreneurship education and at the same time democratic formation can be a difficult task for teacher students when knowing that their design only will be an experimental exercise. "Theoretically, inventing a school garden without doing something was unnecessary." (Student interview June, 2019).

Some teacher students were creating a passive learning atmosphere or felt insecure, uncomfortable and interpreted the freedom to contact and learn from a NGO as a lack of framework and organization of the module. They did not see a potential of democratic formation by learning from people doing something for the common good. Most of the teacher students were positive about working outside the classroom in other settings and they described how this gave them a bit more confidence in challenging themselves as teachers.

The teacher students were expected to participate in activities and take part in workshops and this turned out to be incompatible with their private life and social 
expectations when they were uncertain of the outcome of their efforts. Most of the teacher students showed little interest in developing a prototype and solving practical problems when no students were involved. The game project had a specific outcome and the garden project did not, and this made a significant difference to teacher students' understanding of their learning outcome. Clearly, they considered experiential learning to be more efficient when ending with a usable product than when ending with different abstract options. To learn from Entrepreneurship Education, it is important to work with real challenges, but not always realistic within the present structure of a very theoretical teacher education program.

\section{Conclusion}

For ten years, Danish teacher students have been educated in a system with mandatory entrepreneurship education, but in our sample they did not remember to be introduced Entrepreneurship Education until they enrolled in the teacher education program. In this program, the teacher students expected to meet authentic challenges generated from the teacher profession and to be able to transfer their new knowledge and skills to their future work in a classroom. They wanted to learn through active participation in entrepreneurship education and not just about entrepreneurship education from constructed scenarios. Democratic Formation can be included in Entrepreneurship Education in primary schools. Attitude is understood as an overarching competence influencing creativity, action and outward orientation, but difficult to pinpoint when planning lessons for students in a primary education classroom. The teacher students understood the relationship between entrepreneurship education and democratic formation, and they were able to use it in the concrete examples, and also to feel responsible for the students' development of democratic and entrepreneurial skills. It was complex and risky for the teacher students to focus on so many things at the same time, and once in a while the challenges designed by us were too many.

Entrepreneurship education and the teacher education program must provide authentic learning opportunities for the teacher students, in order to promote entrepreneurial skills.

\section{References}

Arbuthnott, K. D. (2009). Education for sustainable education beyond attitude change. Emerald Group Publishing Limited, 10(2), 152-163.

Ashworth, E., \& Steele, A. (2016). I'm just going to buy that!: Confronting consumerism in teacher education. Discourse and Communication for Sustainable Education, $7(1), 37-48$.

Biesta, G. (2009). Pragmatism's contribution to understanding learning-in-context. In Richard, E., Biesta, G., \& Thorpe, M. (Eds), Rethinking contexts for learning and teaching: Communities, activities and networks (pp. 74-89). London: Routledge.

Biesta, G. (2011). Clearing democracy in school and society: Education lifelong learning and the Politics of Citizenship. Rotterdam: Sense Publishers.

Biesta, G. (2017). The rediscovery of teaching. New York: Routledge.

Biesta, G. et al. (2014). Civic learning, democratic citizenship and the public sphere. Dordrecht: Springer. 
Børne - og Undervisningsministeriet (UVM). (2017). Folkeskolens form 1 [Objectives of the primary school]. Retrieved from https://www.retsinformation.dk/forms/ R0710.aspx?id=196651\#id022b0e44-841e-4caf-9378-363beeaf94c1

Bruun, J., Lieberkind, J., \& Schunck, H. B. (2017). International civic and citizenship education. Internationale hovedresultater. Danmarks Institut for Pædagogik og Uddannelse. Aarhus: Aarhus Universitet.

Dewey, J. (1929). Experience and nature. London: George Allen \& Unwin, Ltd. Retrieved from https://archive.org/details/experienceandnat $029343 \mathrm{mbp} / \mathrm{page} / \mathrm{n} 11$

Eskici, M. (2019). Sustainable learning levels of high school students. Discourse and Communication for Sustainable Education, 10(1), 63-80.

European Commission. (2018). Council Recommendation of 22 May 2018 on Key Competences for Lifelong Learning. Official Journal of the European Union, 189(4).

Jarvis, P. (2010). Adult education and lifelong learning. Theory and practice. Fourth Edition. London: Routledge.

Johansen, P., \& Tetzschner, H. (2006). Casestudiemetoden [Case study method]. In Voxsted, S. (Ed.), Valg der skaber viden [Choises that create knowledge]. Hans Reitzels Forlag.

Korsgaard, O. et al. (2001). Learning for democratic citizenship. Copenhagen: DPU.

McCallum, E., McMullan, L., Weicht, R., \& Price, A. (2018). EntreComp into action, get inspired, make it happen. Luxembourg: Publications Office of European Union.

Rasmussen, A., \& Fritzner, A. (2016). From dream to reality. Learning outcomes and didactic principles for teaching entrepreneurship in Nordic schools. Copenhagen: Nordic Council of Ministers.

Rasmussen, A., Moberg, K., \& Revsbech, C. (2015). A taxonomy of entrepreneurship education - perspectives on goals, teaching and evaluation. Ejlkovsgrade: The Danish Foundation for Entrepreneurship. Retrieved from https://eng.ffe-ye.dk/ media/785766/taxonomy-en.pdf

Rasmussen, C. S., \& Christiansen, R. B. (2007). Medborger og verdensborger - udfordringer for laerere og elever $i$ skolen [Citizen and world citizen - challenges for teachers and students in school]. In KLM i lareruddannelsen [KLM in teacher education]. Frederikshavn: Dafolo Forlag, 61-92.

Report of the World Commission on Environment and Development. Our Common Future. (1987). Retrieved from https://sustainabledevelopment.un.org/content/ documents/5987our-common-future.pdf

Schnack, K. (1992). Dannelse og demokrati [Formation and democracy]. Copenhagen: DLH.

Strachan, G. (2018). Can education for sustainable development change entrepreneurship education to deliver a sustainable future? Discourse and Communication for Sustainable Education, (9)1, 36-49.

Correspondence relating to this paper should be addressed to Britt Due Tiemensma, University College, Absalon, Trekroner Forskerpark 4, 4000 Roskilde. Email: bdt@pha.dk

and Connie Stendal Rasmussen, University College, Absalon, Trekroner Forskerpark 4, 4000 Roskilde. Email: csr@pha.dk 